LISANUL ARAB 10(2)(2021)
(Terakreditasi Sinta 4)
http://journal.unnes.ac.id/sju/index.php/laa

\title{
SEMIOTIKA DALAM LIRIK LAGU 'AL BARQ AL YAMANI' OLEH NISSA SABYAN DAN ADAM ALI
}

\section{Adib Alfalah ${ }^{\bowtie}$, Singgih Kuswardono ${ }^{\bowtie}$ Retno Purnama Irawati ${ }^{\bowtie}$}

Jurusan Bahasa Asing, Fakultas Bahasa dan Seni, Universitas Negeri Semarang, Indonesia

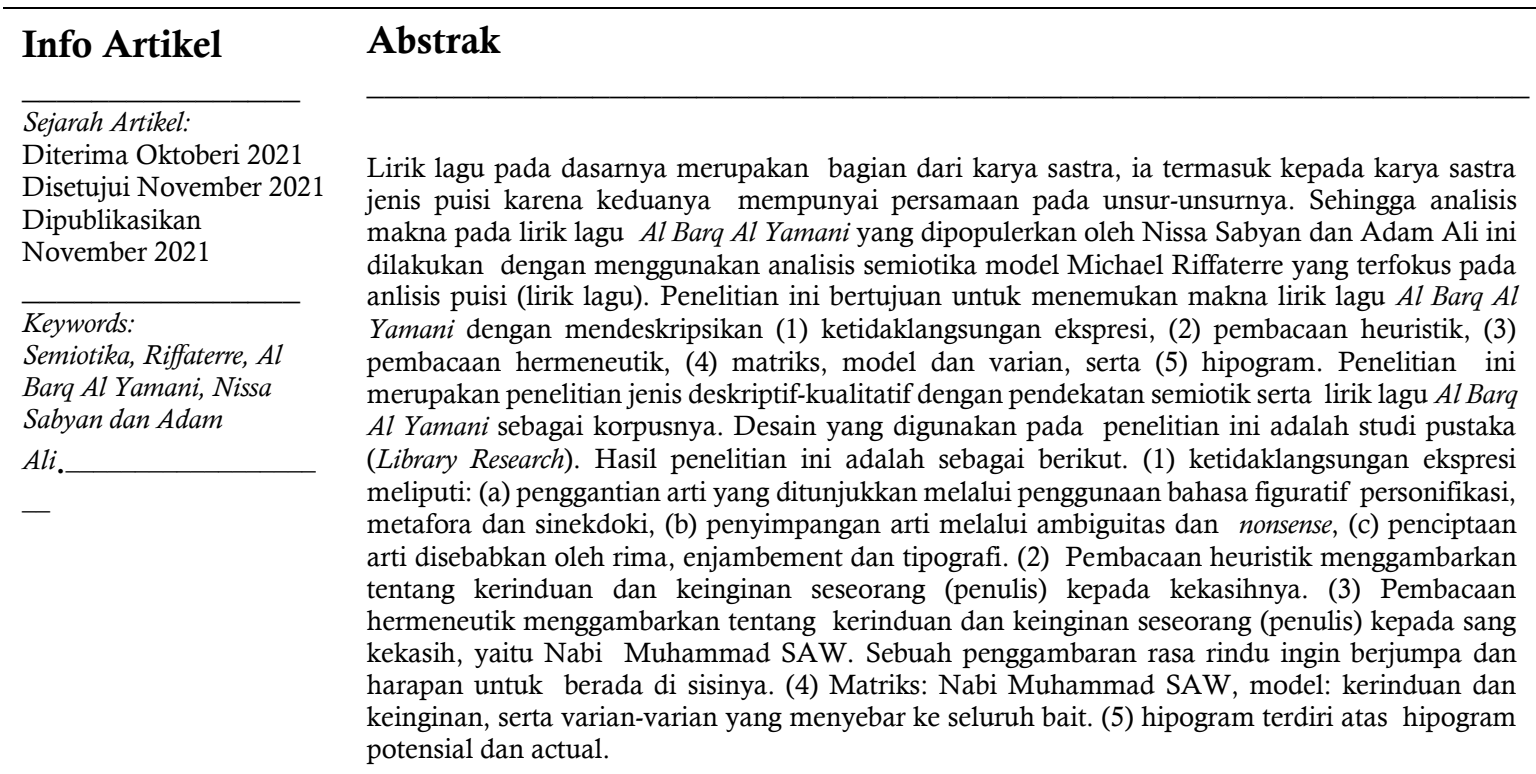

\begin{abstract}
Song lyrics are basically part of literary works, they belong to poetry type literary works because both have similarities in their elements. So the analysis of the meaning of the lyrics of the song $\mathrm{Al}$ Barq Al Yamani which was popularized by Nissa Sabyan and Adam Ali is carried out using a semiotic analysis of Michael Riffaterre's model which focuses on poetry analysis (song lyrics). This study aims to find the meaning ofsong lyrics Al Barq Al Yamani's by describing (1) the unsustainability of the expression, (2) heuristic reading, (3) hermeneutic reading, (4) matrix, model and variant, and (5) hypogram. This research is a descriptive-qualitative research with a semiotic approach and the lyrics of the song Al Barq Al Yamani as its corpus. The design used in this research is library research. The results of this study are as follows. (1) the continuity of expressions includes: (a) displacing of meaning shown through the use of personified figurative language, metaphor and synecdiction, (b) distorsing of meaning through ambiguity and nonsense, (c) creating of meaning caused by rhyme, enjambement and typography (2) The heuristic reading describes the longing and desires of a person (writer) for his lover. (3) Hermeneutic reading describes the longing and desires of a person (writer) for his lover, namely the Prophet Muhammad SAW. A depiction of longing to meet and hope to be by his side. (4) Matrix: Prophet Muhammad SAW, model: longings and desires, as well as variants that spread throughout the verse. (5) Hypogram consists of potential and actual hypograms. .
\end{abstract}

(C) 2021 Universitas Negeri Semarang

\footnotetext{
$\triangle$ Alamat korespondensi:

Gedung B9 Lantai 2 FBS Unnes Kampus Sekaran, Gunungpati, Semarang, 50229

P- ISSN 2252-6269

E-mail:adib.dangerous26@students.unnes.ac.id, singgihkuswardono@mail.unnes.ac.id,

E- ISSN 2721-4222 


\section{PENDAHULUAN}

Viralnya karya lagu-lagu di era milenial saat ini tidak bisa dipungkiri karena semakin canggih dan mudahnya dalam mengakses media sosial. Tidak hanya lagu barat yang berbahasa Inggris ataupun lagu tanah air berbahasa Indonesia saja, namun lagu berbahasa Arab juga termasuk dalam kategori lagu-lagu yang digemari masyarakat Indonesia hingga saat ini. Imron (2018) menyebutkan bahwa penyebab viralnya lagulaagu Arab diantaranya; genre musik dan aransemen yang enak didengar, lirik berbahasa Arab yang sudah tidak asing namun menimbulkan daya tarik tersendiri dibanding lagu lagu berbahasa Indonesia atau bahasa Inggris yang bisa dianggap terlalu sering didengar sehingga cukup membosankan. Sehingga tidak heran jika karya lagu yang berbahasa Arab pun mengalami kesuksesan di era milenial saat ini.

Salah satu musisi kelahiran Pasuruan tahun 1999 bernama Khoirun Nissa semakin dikenal publik seiring dengan melesatnya popularitas grup musik gambus bernama "Sabyan". Grup musik yang sering membawakan lagu bernuansa religi ini mendapat sambutan hangat dari masyarakat berkat aransemen mereka yang unik dan bernuansa islami. Nissa dan grup gambusnya telah menuai banyak karya lagu berbahasa Arab yang semakin populer akhir-akhir ini. Perhatian publik terpatri pada kecantikan dan suara merdu Nissa, serta aransemen musiknya yang unik, modern dan menentramkan hati. Video musiknya yang sering trending di kanal youtube sudah sering diputar hingga jutaan kali, menjadikan karya-karyanya terus berkembang.

Berawal dari rilisan single Sabyan pertengahan tahun 2019, peneliti tertarik untuk mengkaji dan meneliti salah satu lagu yang berjudul "Al Barq Al Yamani". Lagu ini berkisah tentang kerinduan seseorang terhadap sang kekasih (Nabi Muhammad SAW) dan ingin mengunjunginya di Madinah. Lagu $\mathrm{Al} \mathrm{Barq} A l$ Yamani merupakan salah satu lagu yang memiliki beberapa keunikan. Semenjak diunggah di saluran youtube "Sabyan Gambus" pada tanggal 10 Mei 2019, lagu ini sukses menggemparkan dunia maya di Indonesia hingga menduduki posisi trending di kanal youtube. Dari pengamatan peneliti, hingga detik ini (tanggal 01 April 2021) unggahan tersebut telah mencapai lebih dari 19 juta tayangan, 388 ribu suka, 7,4 ribu tidak suka dan 40 ribu komentar. Sebuah karya lagu yang sukses dan berhasil menduduki posisi trending di youtube, membuktikan bahwa lagu tersebut diterima dan disukai oleh masyarakat Indonesia terkhusus bagi penikmat musik dan para penggemar Sabyan Gambus.

Dibalik lagu "Al Barq Al Yamani", kali ini Nissa Sabyan memberikan sesuatu yang berbeda dari lagu-lagu sebelumnya. Musisi dari grub Gambus Sabyan ini berkolaborasi dengan Adam Ali, seorang musisi asal Lebanon. Lebanon merupakan salah satu negara dengan penggunaan bahasa resmi bahasa Arab. Tidak hanya itu saja, peneliti menemukan sesuatu yang luar biasa, bahwa penggarapan lagu $\mathrm{Al}$ Barq Al Yamani ini ternyata juga melibatkan musisi-musisi internasional, seperti Adam Ali sebagai composer dan arranger, Jean Madani sebagai mixer di Beirut Lebanon dan Mastering oleh Khalil Chanine di Berlin Germany serta lirik lagu yang bersumber dari Islamic Nashid Heritage. Kemudian sisi lain yang menjadi perhatian ialah perpaduan lirik lagu yang berbahasa Arab dan berbahasa Inggris, menjadikan lagu ini lebih modern dan sesuai dengan generasi milenial saat ini.

Lagu "Al Barq Al Yamani" termasuk lagu bernuansa religi yang mudah diterima oleh banyak kalangan, karena pada dasarnya lagu dan iringan musiknya yang asik dan enak didengar, serta menggunakan bahasa Arab fushah. Akan tetapi untuk memahami lebih lanjut terkait makna yang terkandung didalamnya, dirasa khalayak umum masih minim tingkat pemahamanya. Apalagi mereka yang tidak tahu bahasa Arab atau sama sekali belum pernah belajar bahasa Arab. Bahkan, untuk mereka yang mungkin bisa berkomunikasi dan pernah belajar bahasa Arab pun belum tentu bisa memahami makna dan pesan nya secara utuh.

Mengingat bahwa lagu merupakan salah satu media komunikasi audio, lagu juga menjadi media yang efektif untuk menyampaikan pesan. Lagu yang dikemas dengan iringan musik tidak lagi menjadi media hiburan semata, tetapi juga dapat digunakan sebagai media untuk menyalurkan aspirasi individu, kelompok hingga masyarakat luas. Sebagian besar orang menyanyikan sebuah lagu bertujuan untuk menghibur diri sendiri ataupun orang lain, akan tetapi tidak menutup kemungkinan seseorang menyanyikan sebuah 
lagu karena ingin mengekspresikan siapa dan bagaimana sosok dirinya tersebut. Melalui lagu, seseorang ingin menjelaskan, menghibur, mengungkapkan makna suatu pesan, sekaligus mempengaruhi perasaan orang yang mendengarkanya melalui sebuah lirik.

Salah satu komponen penting sebuah lagu dalam ketercapaian penyampaian pesan terletak pada lirik lagunya. Ibaratnya lirik adalah suatu alat pendukung ketercapaianya dalam menyampaikan pesan. Proses pertukaran simbol dapat dilakukan melalui sebuah lirik. Lirik pada praktiknya dapat bermula dari bentuk yang bermacam-macam, bisa dari sebuah prosa, puisi, atau memang sejak awal suatu lirik telah ditulis untuk dilagukan. Menurut Siswantoro (2010 : 23) lirik lagu merupakan bagian dari karya sastra, ia termasuk kepada karya sastra jenis puisi. Seperti halnya puisi, lirik lagu juga memiliki unsur seperti bunyi, kata, larik dan bait yang dapat mewujudkan ekspresi dan emosi yang ingin disampaikan oleh pengarang tentang suatu hal yang sudah dilihat, didengar maupun dialaminya. Dalam mengekspresikan perasaan dan pengalamanya, pengarang melakukan permainan kata-kata dan bahasa untuk memunculkan daya tarik dan kekhasan terhadap lirik seperti halnya keindahan sebuah syair. Sehingga lirik lagu termasuk bentuk pengungkapan puisi karena kemiripan unsurunsur pembentuknya.

Dari penjelasan diatas, dapat disimpulkan bahwa puisi dan lirik lagu memiliki unsur pembentuk yang sama, oleh karena itu puisi dan lirik lagu memiliki keterkaitan yang dapat dianalisis menggunakan metode dan teori yang sama. Sehingga untuk mencari makna suatu lirik lagu, teori yang paling cocok adalah teori semiotik Michael Riffaterre karena analisisnya mengarah kepada pemberian makna kepada puisi ataupun lirik lagu.

Untuk mencari makna dari sebuah karya sastra, menurut Riffaterre sebagaimana dikutip Saputra (2020:2) dalam bukunya Semiotics of Poetry menyebutkan ada empat pokok yang harus diperhatikan, yaitu (1) ketidaklangsungan ekspresi puisi, (2) pembacaan heuristik dan hermeneutik atau retroaktif, (3) matriks, model dan varian-varian, dan (4) hipogram (hubungan intertekstual).

\section{LANDASAN TEORI}

\section{Semiotika}

Kata semiotika diturunkan dari bahasa inggris, yaitu semiotics. Berpangkal pada Pedoman Umum Ejaan Bahasa Indonesia yang disempurnakan dan Pedoman Umum Pembentukan Istilah (Produksi Pusat Pembinaan dan Pengembangan Bahasa) bahwa orientasi pembentukan istilah itu ada pada bahasa Inggris. Akhiran bahasa Inggris -ics dalam bahasa Indonesia berubah menjadi $-i k$ atau $-i k a$, misalnya, dialectics berubah menjadi dialektik atau dialektika; aesthetics berubah menjadi estetik atau mekanik estetika, dan mechanics berubah menjadi atau mekanika. Nama lain semiotika adalah semiologi. Keduanya, memiliki pengertian yang sama, yaitu sebagai ilmu tentang tanda. Baik semiotika maupun semiologi berasal dari bahasa Yunani, yaitu semeion yang berarti tanda (Santosa, 2013: 2-3). Menurut Eco, sebagaimana dikutip Sobur (2004:95) tanda itu sendiri didefinisikan sebagai sesuatu yang atas dasar konvensi sosial yang terbangun sebelumnya, dapat dianggap mewakili sesuatu yang lain. Secara terminologis, semiotik dapat didefiniskan sebagai ilmu yang mempelajari sederetan luas objek-objek, peristiwa-peristiwa, seluruh kebudayaan sebagai tanda.

Menurut Van Zoest sebagaimana dikutip Sudjiman (dalam Santosa, 2013: 4) mendefinisikan semiotika adalah studi tentang tanda dan segala yang berhubungan dengannya: cara berfungsinya, hubungannya dengan tandatanda lain, pengirimannya, dan penerimaannya oleh mereka yang mempergunakannya. Secara khusus semiotika dibagi atas 3 bagian utama, yaitu (1) sintaks semiotik, studi tentang tanda yang berpusat pada penggolongannya, pada hubungannya dengan tanda-tanda lain, dan pada caranya bekerja sama menjalankan fungsinya; (2) semantik semiotik, studi yang menonjolkan hubungan tanda-tanda dengan acuannya dan interpretasi yang dihasilkannya; dan (3) pragmatik semiotik, studi tentang tanda yang mementingkan hubungan antara tanda dengan pengirim dan penerima

\section{Semiotika Michael Riffaterre}

Michael Riffaterre memiliki nama asli Michael Camille Riffaterre. Ia dilahirkan di Bourganeuf, Prancis pada tanggal 20 November 
1924 dan meninggal di rumahnya Manhattan, New York, Amerika pada tanggal 27 Mei 2006. Ia merupakan kritikus sastra Amerika yang menekankan pada analisis tekstual sebagai respons pembaca, bukan pada biografi maupun sikap politik pengarang. Riffaterre mempertahankan prinsip-prinsipnya sebagai seorang strukturalis dalam karyanya yang fenomenal yakni Semiotics Of Poetry (1978). Selanjutnya pada tahun 1979 ia menerbitkan karyanya yang berjudul "La Prodiction du texte" dan "Fictional Truth" pada tahun 1989. Riffaterre menjadi general editor pada "The Romaniac Review" (1971-2000) (Fajrin, 2019: 149).

Semiotika Riffaterre pada mulanya muncul atas penolakan terhadap semiotika Jakobson. Dalam analisisnya, Jakobson hanya memperlihatkan aspek linguistik dalam pengertiannya terbatas dan mengabaikan aspekaspek lain, seperti aspek pragmatik dan ekpresif dimana peran pembaca dan penulis bisa diungkap. Jakobson juga meremehkan aspek referensial sehingga mengakibatkan hilangnya relevansi sosial karya sastra, dan sastra menjadi sesuatu yang tergantung di awang-awang. Menurut Riffaterre, yang menentukan apakah sajak (puisi) bagus atau tidak adalah si pembaca sajak, bukan seorang linguis (ahli bahasa) yang menganalisis sajak tersebut. Dengan segala pengalaman pembaca yang ia miliki, pembaca mampu menentukan kualitas sebuah sajak termasuk di dalamnya hal-hal yang relevan serta fungsi puitis sebuah sajak, Teeuw sebagaimana dikutip Imaduddin (2018:9).

Untuk mencari makna dari sebuah karya sastra, menurut Riffaterre sebagaimana dikutip Saputra (2020:2) dalam bukunya Semiotics of Poetry menyebutkan ada empat pokok yang harus diperhatikan, yaitu (1) ketidaklangsungan ekspresi puisi, (2) pembacaan heuristik dan hermeneutik atau retroaktif, (3) matriks, model dan varianvarian, dan (4) hipogram (hubungan intertekstual).

\section{Ketidaklangsungan Ekspresi}

Ketidaklangsungan ekspresi menurut Riffaterre, sebagaimana dikutip Aryanto (2013:52-53) disebabkan oleh tiga hal, yaitu penggantian arti (displasing of meaning), penyimpangan arti (distorting of meaning), dan penciptaan arti (creating of meaning). Ketiga jenis ketidaklangsungan ini akan mengancam representasi kenyataan atau apa yang disebut dengan mimesis. Landasan mimesis adalah hubungan langsung antara kata dengan objek. Pada tataran ini, masih terdapat kekosongan makna tanda yang perlu diisi dengan melihat bentuk ketidaklangsungan ekspresi untuk menghasilkan sebuah pemaknaan baru (significance).

\section{a. Penggantian Arti (displacing of meaning)}

Penggantian arti disebabkan oleh bergesernya arti dari suatu kata ke arti yang lain, atau ketika sebuah kata mewakili kata yang lain dengan menggunakan bahasa kiasan, bahasa kiasan ini disebut dengan metafora dan metonimi. Metafora dan metonimi ini dalam arti luasnya untuk menyebut bahasa kiasan pada umumnya seperti simile, metafora, personifikasi, alegori, metonimi, sinekdoki dan perumpamaan epos. Menurut Sayuti, sebagaimana dikutip Syafethi (2016:14) dalam pergantian arti ini suatu kata atau tanda memiliki arti lain (tidak menurut arti sesungguhnya). Penggunaan bahasa kias adalah sebagai alat untuk memperoleh efek puitis dalam puisi. Bahasa kiasan mencakup semua jenis ungkapan berupa kata, frasa ataupun kalimat yang memiliki makna lain dengan makna harfiahnya. Bahasa kias ini berfungsi untuk menggugah tanggapan pembaca serta mengetengahkan sesuatu yang berdimensi banyak dalam bentuk yang sesingkat-singkatnya.

\section{b. Penyimpangan Arti (distorsing of meaning)}

Riffaterre menyebutkan bahwa penyimpangan arti disebabkan oleh tiga hal, yaitu ambiguitas (makna ganda), kontradiksi (makna yang berlawanan), dan nonsense (rangkaian bunyi namun memiliki makna) (Saputra, 2020:22).

\section{c. Penciptaan Arti (creating of meaning)}

Menurut Riffaterre, sebagaimana dikutip Syafethi (2016:21) penciptaan arti terjadi jika ruang teks berlaku sebagai prinsip pengorganisasian untuk membuat tanda tanda keluar dari hal-hal ketatabahasaan yang secara lingustik tidak ada artinya, misalnya simitri, rima, enjambement, atau semantik di antara persamaan-persamaan posisi dalam bait (homologues). Penciptaan arti ini biasanya secara lingual tidak memiliki makna yang jelas, 
namun ketika ditafsirkan secara keseluruhan ternyata memiliki makna yang dalam. Dengan kata lain penciptaan arti disebabkan oleh rima, enjambement, dan tipografi. Dalam puisi sering terdapat keseimbangan (simitri) berupa persejajaran arti antara bait-bait atau antara baris-baris dalam bait. Selain itu juga terdapat repitisi, yaitu gaya bahasa penegasan yang mengulang-ulang suatu kata, frase, atau kalimat, baris atau bait. Adanya repitisi yaitu untuk memberikan efek penegasan makna yang ingin disampaikan penyair.

\section{Pembacaan Heuristik dan Hermeneutik}

\section{a. Pembacaan Heuristik}

Pembacaan heuristik disebut juga dengan parafrase, yaitu proses memparagrafkan atau menarasikan suatu puisi. Pembacaan heuristik adalah pembacaan dalam taraf mimesis. Pembacaan itu didasarkan pada sistem dan konvensi bahasa. Mengingat bahasa memiliki arti referensial, maka untuk menangkap arti, pembaca harus memiliki kompetensi linguistik. Pembacaan heuristik, pada dasarnya merupakan interpretasi tahap pertama, yang bergerak dari awal ke akhir teks sastra, dari atas ke bawah mengikuti rangkaian sintagmatik. Pembacaan tahap pertama ini akan menghasilkan serangkaian arti yang bersifat heterogen (Hosen \& Ramadhani, 2020:4).

Dalam pembacaan ini, sajak dibaca berdasarkan konvensi bahasa atau sistem bahasa sesuai dengan kedudukan bahasa sebagai sistem semiotik tingkat pertama. Sajak dibaca secara linear sebagai dibaca menurut struktur normatif bahasa (bahasa sehari-hari). Pada umumnya, bahasa puisi menyimpang dari penggunaan bahasa biasa (bahasa normatif). Bahasa puisi merupakan deotomisasi atau defamiliarisasi: ketidakotomatisan atau ketidakbiasaan. Ini merupakan sifat kepuitisan yang dapat dialami secara empiris, Shklovsky, sebagaimana dikutip Pradopo (dalam Saputra, 2020:23).

\section{b. Pembacaan Hermeneutik}

Cara kerja hermeneutik untuk penafsiran karya sastra, menurut Teeuw sebagaimana dikurip Nurgiyantoro (dalam Saputra, 2020:24-25) dilakukan dengan pemahaman keseluruhan berdasarkan unsur- unsurnya, dan sebaliknya. Dari sinilah kemudian muncul istilah lingkaran hermeneutik (hermeneutic circle). Pemahaman karya sastra dengan teknik tersebut dapat dilakukan secara bertangga, dimulai dengan pemahaman secara keseluruhan walau hal itu hanya bersifat sementara. Kemudian berdasarkan pemahaman yang diperoleh itu dilakukan kerja analisis dan pemahaman unsur-unsur intrinsiknya, jadi bagian per bagian. Pada giliran selanjutnya, hasil pemahaman unsur-unsur intrinsik tersebut dipergunakan dan lebih banyak menyanggupkan kita, untuk memhami keseluruhan karya yang bersangkutan secara lebih baik, luas, dan kritis. Demikian seterusnya dengan pembacaan berulang-ulang sampai akhirnya kita dapat menafsirkan pertautan makna keseluruhan dan bagian bagiannya dan makna intensionalnya secara optimal.

\section{Matriks, Model dan Varian}

Konsep dasar ketiga yaitu yang menurut Riffaterre dinamakan dengan matriks, model dan varian. Dengan mengutip penjelasan lain bahwa karya sastra merupakan hasil transformasi matriks, yaitu sebuah kalimat minimal yang harfiah, menjadi bentuk yang lebih panjang, kompleks, dan tidak harfiah. Matriks adalah kata kunci atau intisari dari serangkaian teks. Matriks bersifat hipotesis dan di dalam struktur teks hanya terlihat sebagai aktulalisasi kata-kata. Matriks bisa saja berupa sebuah kata, gabungan, bagian kalimat atau kalimat sederhana dan dalam hal ini tidak pernah muncul di dalam teks (Imaduddin, 2018:13). Matriks menjadi sebuah sumber dari seluruh makna yang ada dalam karya sastra.

Sebuah puisi berawal dari adanya matriks. Puisi merupakan hasil dari penjabaran sebuah matriks. Matriks ini dapat berupa satu kata, gabungan kata, bagian kalimat atau kalimat sederhana, yang dijabarkan menjadi satu penjabaran yang lebih panjang dan kompleks, Riffaterre sebagaimana dikutip Saputra (2020:26). Hal ini menerangkan bahwa matriks memberikan makna kesatuan sebuah puisi, sehingga dengan diketahuinya matriks pada puisi, dapat dikatakan bahwa pembaca telah mengetahui tema puisi tersebut.

Matriks kemudian diaktualisasikan dalam bentuk model, sesuatu yang terlihat dalam teks puisi. Model dapat pula dikatakan sebagai aktualisasi pertama dari matriks. 
Model merupakan kata atau kalimat yang dapat mewakili bait dalam puisi. Bentuk penjabaran dari model dinyatakan dalam varian-varian yang terdapat dalam tiap baris atau bait. Matriks dan model merupakan varian-varian dari struktur yang sama. Dengan kata lain, puisi merupakan perkembangan dari matriks menjadi model kemudian ditransformasikan menjadi varian-varian.

\section{Hipogram}

Riffaterre menyebutkan bahwa hipogram terdiri dari dua macam, yaitu hipogram potensial dan hipogram aktual. Hipogram potensial adalah hipogram yang tampak dalam karya sastra, segala bentuk implikasi dari makna kebahasaan yang telah dipahami dari suatu karya sastra. Hipogram ini dapat berupa presuposisi, sistem deskripsi dan makna konotasi yang terdapat dalam suatu karya sastra. Hipogram potensial tidak tereskplisit dalam teks, tetapi harus diabstraksikan dari teks. Hipogram potensial itu adalah matriks yang merupakan inti teks atau kata kunci, dapat berupa suatu kata, frase, atau kalimat sederhana. Bentuk implikasi tersebut tidak terdapat dalam kamus namun sudah ada dalam pikiran kita sendiri. Hipogram aktual merupakan keterkaitan teks dengan teks yang sudah ada sebelumnya (Saputra, 2020:2728) Hipogram aktual dapat berupa teks nyata, kata, kalimat, peribahasa, atau seluruh teks dan terwujud dalam teks yang ada sebelumnya, baik berupa mitos, maupun karya sastra lainnya.

\section{Musik}

Musik merupakan suatu cerminan kebudayaan hasil kesenian di dalam suatu masyarakat. Didalam musik sendiri, terkandung nilai-nilai dan norma aturan yang menjadi bagian dari enkulturasi budaya masyarakat tertentu. Musik ialah buah rasa, pikiran dan ekspresi hasil dari seni tarik suara yang dikombinasikan dengan alat-alat musik dan irama yang dihasilkanya sebagai spirit (dorongan) bagi pendengarnya. Sehingga suara atau bunyi merupakan salah satu elemen musik paling dasar. Menurut Setywan (2019:37) suara musik yang baik adalah hasil interaksi dari tiga elemen, yaitu : irama, melodi, dan harmoni. Irama adalah pengaturan suara dalam suatu waktu, panjang, pendek dan temponya. Hal ini memberikan karakter tersendiri pada setiap musik. Kombinasi beberapa tinggi nada dan irama akan menghasilkan melodi tertentu.
Selanjutnya, kombinasi yang baik antara irama dan melodi melahirkan bunyi yang harmoni.

Jika melihat realita dan kondisi saat ini, seni musik bergenre pop, dangdut, rock dan religi merupakan genre musik yang sangat populer. Kehadiranya disambut sangat antusias oleh masyarakat. Menurut Setywan (2019:39) sangat berbeda pada saat masih zaman kerajaan, musik hanya diperbolehkan disebuah kerajaan ketika ada pesta besar itupun dengan menggunakan musik gambus. Dengan adanya mobilitas musik gambus sudah jarang diminati. Karena banyak bermunculan group band ataupun penyanyi solo yang lebih berbakat dan kehadiranya lebih gampang diterima masyarakat. Namun tidak disangka bahwa keberadaan gambus saat ini kembali terdengar, bahkan mencapai titik popularitas di tengahtengah ramainya musik tanah air. Sebut saja Gambus Sabyan. Musik bergenre gambus yang akan peneliti jadikan sebagai penelitian. Sampai saat ini Gambus Sabyan mampu memberikan karya-kaya terbaiknya, tentunya dengan kemudahan akses sosial di beberapa media sosial yang lebih memudahkan musik tanah air dikenal dan dinikmati masyarakat luas.

\section{Lirik Lagu}

Lirik lagu sebagai salah satu unsur pembangun dalam lagu atau musik dapat dikategorikan sebagai puisi dalam karya sastra. Menurut Semi sebagaimana dikutip Hermintoyo (dalam Saputra, 2020:18) menyebutkan bahwa "lirik adalah puisi pendek yang mengekspresikan emosi". Sedangkan menurut Kamus Besar Bahasa Indonesia lirik adalah (1) karya sastra (puisi) yang berisi curahan perasaan pribadi; (2) susunan kata sebuah nyanyian. Dengan begitu lirik lagu juga merupakan sebuah karya sastra sama dengan puisi.

Lirik lagu merupakan ekspresi sesorang tentang suatu hal yang telah dilihat, didengar maupun dialaminya. Dalam mengekspresikan pengalamanya, pencipta lagu melakukan permainan kata-kata dan bahasa untuk menciptakan daya tarik dan kekhasan terhadap lirik lagunya. Permainan bahasa ini dapat berupa permainan vokal,gaya bahasa maupun penyimpangan makna kata dan diperkuat dengan penggunaan melodi dan notasi musik yang disesuaikan dengan lirik lagunya sehingga pendengar semakin terbawa dengan apa yang dipikirkan pengarangnya, 
Awe sebagaimana dikutip

Hidayat (2014;246-247). Lirik atau syair secara sederhana adalah kata-kata pada lagu. Lirik pada sebuah lagu berperan tidak hanya sebagai pelengkap lagu tetapi juga sebagai bagian terpenting yang mana akan menentukan sebuah tema dari lagu tersebut. Lirik lagu dapat menggambarkan suasana serta makna yang terkandung sekaligus menciptakan rasa tertentu seperti senang, sedih, semangat, bagi para pendengarnya (Imron, 2018:19).

\section{METODE PENELITIAN}

Penelitian ini merupakan jenis
penelitian deskriptif-kualitatif dengan
pendekatan semiotik serta lirik lagu Al Barq $A l$
Yamani sebagai korpusnya. Desain yang
digunakan pada penelitian ini adalah studi
pustaka (Library Research). Peneliti mengkaji
teori-teori yang mendasari penelitian ini serta
kegiatanya yang berkenaan dengan metode
pengumpulan data pustaka, membaca, dan
mencatat serta mengolah bahan penelitian.

Dalam proses penelitian ini, langkah analisis data yang dilakukan adalah pemilihan teks lirik lagu "Al Barq Al Yamani". Teknik analisis data yang digunakan dalam penelitian ini menggunakan analisis semiotika model Michael Riffaterre. Dalam menganalisa lirik lagu "Al Barq Al Yamani", peneliti menggunakan tahapan analisis yang termuat dalam bukunya Semiotics of Poetry, yaitu :

1) Menemukan ketidaklangsungan ekspresi

2) Pembacaan heuristik

3) Pembacaan hermeneutik

4) Menemukan matriks, model dan varian

5) Menemukan hipogram

Dalam pengumpulan data tersebut, peneliti mengambil sebuah teks lirik lagu pada channel resmi "Sabyan Gambus" dan "JoinAdamAli" yang dipublikasikan melalui media Youtube dan beberapa sumber yang lainya. Teknik pengumpulan data dalam penelitian ini adalah menggunakan teknik simak dan teknik catat. Pada tahap pengumpulan data, peneliti menggunakan kartu data sebagai instrumen penelitian untuk mempermudah mengumpulkan, mengolah dan menganalisis data.

\section{HASIL PEMBAHASAN}

Lagu Al Barq Al Yamani merupakan lagu yang sebagian besar memainkan pengulangan bait lirik. Maka dari itu sebelum menuju pada tahapan-tahapan analisis, peneliti membagi teks lirik lagu Al Barq Al Yamani menjadi 6 bagian bait yang mewakili keseluruhan lirik untuk mempermudah proses analisis. Berikut bagian

bagian baitnya :

Bagian bait ke-1

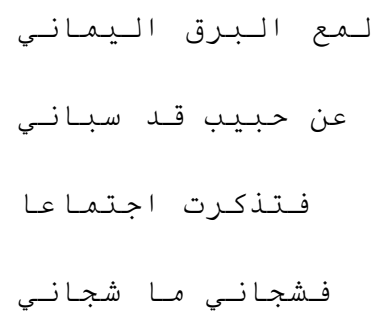

Bagian bait ke-2

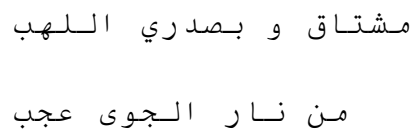

Bagian bait ke-3

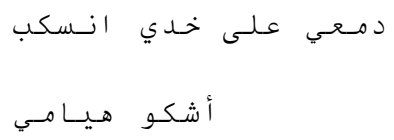

Bagian bait ke-4

To Madina I wanna go

I wanna soothe my aching soul

And see the green beatiful dome

And visit the best man of all 
Bagian bait ke-5

In madina I'd love to be

And see the death come upon me

Be buried in Al Baqi

Close to the best human being

Bagian bait ke-6

طلع الـبـد ر علـيـنـا مـن ثـنـيـات الـورد اع

وجب الـشكر علـيـنـا مـا دعـا هـل د اعي

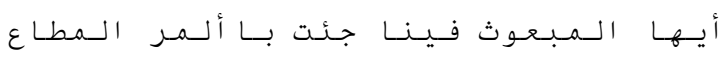

جــت شرفـت الـمـديـنـة مـرحبـا يـا خــــر د اع

Param, pam, pam, param

\section{Ketidaklangsungan Ekspresi}

Berikut analisis ketidaklangsungan ekspresi pada lirik lagu Al Barq Al Yamani oleh Nissa Sabyan dan Adam Ali :

Bagian bait ke-1 :

Bila ditinjau dari segi ketidaklangsungan ekspresi, penulis mengekspresikan syairnya dengan bahasa yang sederhana. Namun, pada bait tersebut menunjukkan penggantian arti, penyimpangan arti dan penciptaan arti. الـبـرق> Penggantian arti telihat pada ungkapan $<$ yang mempunyai makna pokok "kilat". Akan tetapi kata tersebut merupakan suatu kiasan personifikasi yang menunjukkan representasi dari seseorang yang mampu menerangi kegelapan dan menunjukkan pada jalan yang benar (Nabi Muhammad SAW). Selanjutnya terdapat metafora pada ungkapan حبيب> >yang mempunyai makna pokok "sang kekasih". Kata tersebut merupakan ungkapan untuk orang yang dicintai dan dikasihinya (Nabi Muhammad SAW). Sang penulis melantunkan ungkapan "sang kekasih" secara tidak langsung ia memberikan pujian bagi seseorang tersebut.

Selain itu ditemukan pula penyimpangan arti pada pada bait tersebut, yaitu pada ungkapan $>$ ش ش > Ungkapan kata tersebut merupakan suatu ambiguitas, yang mana ia mempunyai makna ganda yaitu "menyedihkan" dan "menggembirakan". Namun bila ditinjau dari kesesuaian konteks, makna yang tepat ialah menggembirakan (bersuka cita).

Pada bait ini, terdapat penciptaan arti berupa rima patah (a-a-b-a). Kemudian pada baris terakhir pada ungkapan bersuka cita > شجانـي menunjukkan adanya pengulangan kata (majas repitisi/penegasan) yang memberikan penegasan sajak dan pengulangan ini terasa intens, penulis ingin mengekspresikan perasaan gembiranya yang berkobar-kobar. Setelah itu terdapat pula enjambement pada tiap perpindahan barisnya. Antara baris 1-2 dan 3-4 menunjukkan penggalan kata yang masih berkaitan maknanya. Baris tersebut juga memberikan penegasan dan penekanan bahwa kilat Yaman telah membuat si penulis bernostalgia.

\section{Bagian bait ke-2 :}

Bila ditinjau dari segi ketidaklangsungan ekspresi, penulis syair mulai menggunakan permainan bahasa viguratif yang indah. Sehingga pada bait tersebut menunjukkan adanya penggantian arti, penyimpangan arti dan penciptaan arti. Penggantian arti pada bait ini yaitu adanya metafora pada ungkapan الــــ

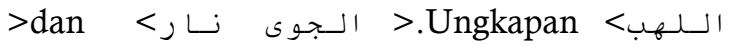
$<$ mempunyai makna pokok "bergejolak", akan tetapi ia mempunyai makna kiasan yang menunjukkan makna rindu yang begitu dalam bagaikan nyala api yang berkobar-kobar. Kemudian ungkapan السجوى > > الس > mempunyai makna secara harfiah yaitu "api jarak". Api jarak disini menunjukkan betapa jauhnya jarak yang memisahkan, sehingga diibaratkan seperti api yang membuat dadanya bergejolak karena rindu yang begitu dalam.

Penyimpangan arti pada bait tersebut ditunjukkan pada ungkapan عجب> > yang berarti "menakjubkan". Namun jika disesuaikan dengan konteks untuk mendapatkan makna yang mudah dipahami, makna yang tepat ialah "memisahkan".

Penciptaan arti pada bait tersebut terdapat rima dan enjambement. Bait ini mempunyai rima jenis kembar (a-a) yang mana pada baris ke-1 dan ke-2 mempunyai bunyi akhir yang sama. Kemudian antara baris 1-2 menunjukkan penggalan kata yang masih berkaitan maknanya. Baris tersebut juga memberikan penegasan dan penekanan 
bahwa antara rindu dan jarak sama-sama begitu hebatnya.

Bagian bait ke-3 :

Bila ditinjau dari segi ketidaklangsungan ekspresi, pada bait ini bisa dikatakan bahwa penulis mengungkapkan dengan bahasa yang sederhana dan terbuka. Sehingga jika seseorang membaca syair ini, dapat dengan mudah untuk memahami. Maka dari itu pada bait tersebut tidak ditemukan ungkapan penggantian arti, akan tetapi terdapat penyimpangan arti dan penciptaan arti. Pada ungkapan أشكو أشيخ ambiguitas. Kata tersebut menunjukkan makna yang multitafsir, secara harfiah berarti "mengeluhkan", akan tetapi jika disesuaikan dengan konteks makna yang tepat yaitu "mengekspresikan/menunjukkan".

Kemudian antara baris 1-2 menunjukkan penggalan kata yang masih berkaitan maknanya. Baris tersebut juga memberikan penegasan dan penekanan bahwa air mata merupakan buah dari adanya kerinduan yang mendalam. Rima dalam bait ini disebut rima silang $(a-b)$.

Bagian bait ke-4 :

Bila ditinjau dari segi ketidaklangsungan ekspresi, terdapat beberapa ungkapan yang menunjukkan penggantian arti, penyimpangan arti dan penciptaan arti. Penggantian arti ditunjukkan pada 2 ungkapan yang menunjukkan penggunaan sinekdoke pras pro toto, yaitu kiasan yang menyebutkan sebagian untuk keseluruhan terdapat pada ungkapan "soul" dan "the green beautiful dome". Ungkapan "soul"/jiwa menunjukkan makna sebagian (jiwa) untuk keseluruhan (manusia), sementara ungkapan "The green beautiful dome"/kubah hijau yang indah menyebutkan makna sebagian (kubah) untuk keseluruhan (masjid). Makna dari kubah hijau yang dimaksud dari kalimat tersebut ialah Masjid Nabawi yang bertempat di Madinah, Arab Saudi. Selain itu terdapat ungkapan "The best man of all" merupakan kiasan majas metafora, yang secara harfiah bermakna "manusia terbaik". Manusia terbaik disini mengandung makna pujian kepada Nabi Muhammad SAW.

Ungkapan "aching soul" menunjukkan penyimpangan arti ambiguitas. Ungkapan tersebut mempunyai makna ganda, yakni sakit jiwa (hilang akal) dan sakit secara batin (perasaan, pikiran, angan-angan). Arti yang tepat pada konteks ini adalah sakit secara batin. Sang penulis membutuhkan obat dan penyejuk bagi dirinya sendiri.Selain itu, pada bait ini juga menunjukkan adanya permainan rima yaitu rima silang (a-b-a-b). Kemudian terdapat pula majas repitisi (penegasan) pada baris ke1-2 yaitu pada ungkapan "I wanna" dan pada baris ke3-4 yaitu ungkapan "and". Adanya rima silang, semakin memperindah ungkapan syair pada bait tersebut. Kemudian antara baris 1-2 dan 3-4 menunjukkan penggalan kata yang masih berkaitan maknanya. Baris tersebut juga memberikan penegasan dan penekanan bahwa ke empat baris tersebut merupakan sebuah keinginan berkelanjutan sang penulis.

Bagian bait ke-5 :

Bila ditinjau dari segi ketidaklangsungan ekspresi , terdapat beberapa ungkapan yang menunjukkan penggantian arti dan penciptaan arti. Penggantian arti ditunjukkan pada ungkapan "the best human being". Ungkapan "the best human being" merupakan kiasan majas metafora, yang secara harfiah bermakna "manusia terbaik". Manusia terbaik disini mengandung makna pujian kepada Nabi Muhammad SAW.

Pada bait tersebut juga menunjukkan adanya permainan rima kembar (a-a-a-a) yang memperindah lantunan syair. Kemudian terdapat pula majas repitisi (penegasan) pada ungkapan "Madina"/Madinah. Ungkapan tersebut merupakan bentuk pengulangan kata dari bagian bait keempat sebelumnya, yang mana pengulangan tersebut memberikan penegasan makna, bahwa sang penulis berkeinginan kuat untuk pergi ke Madinah. Selain itu, antara baris 1-2 dan 3-4 menunjukkan enjambement (penggalan kata) yang masih berkaitan maknanya. Baris tersebut juga memberikan penegasan dan penekanan bahwa ke empat baris tersebut merupakan sebuah keinginan berkelanjutan sang penulis.

\section{Bagian bait ke-6 :}

Bila ditinjau dari segi ketidaklangsungan ekspresi, terdapat beberapa ungkapan yang menunjukkan adanya penggantian arti, penyimpangan arti dan penciptaan arti. Penggantian arti pada bait tersebut ditunjukkan oleh ungkapan الـبـدرا>

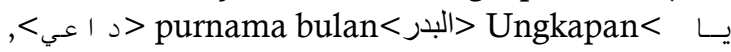




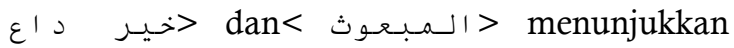
makna kiasan seseorang yang mampu menerangi dan menunjukkan jalan kebenaran. Kemudian ungkapan د ا اعي> penyeru menunjukkan makna kiasan seseorang yang mengemban tugas penting menyebarkan agama islam. Selanjutnya ungkapan l>/sang utusan menunjukkan makna kiasan seseorang yang terpilih oleh Allah SWT sebagai utusan-Nya untuk menyampaikan wahyu kepada umat manusia. Yang terakhir adalah ungkapan $<\varepsilon^{\prime}$ د > > > > sebaik-baik penyeru yang menunjukkan makna kiasan pujian kepada seseorang yang mengemban tugas penting menyebarkan agama islam. Dapat disimpulkan bahwa dari keempat ungkapan penggantian arti tersebut merupakan bahasa viguratif majas metafora, suatu kiasan yang memuji Nabi Muhammad SAW.

Sementara itu, ungkapan yang menunjukkan penyimpangan arti dalam bait tersebut terdapat pada kalimat "Param, pam, pam, param" yang merupakan sebuah non sense. Gabungan kata tersebut secara lingustik tidak memiliki arti, karena kata tersebut diciptakan sendiri oleh pengarang. Meskipun demikian, kata tersebut tetap memiliki makna. Kata-kata tersebut merupakan penggugah semangat, mengekspresikan perasaan riang gembira manakala menyambut kedatangan Nabi Muhammad SAW. Sehingga memberikan kesan pada lagu dan menghidupkan suasana lagu yang temponya up-beat.

Pada bait syair tersebut terdapat permainan rima yang menunjukkan jenis rima kembar (a-a-a-a). Kemudian terdapat pula pengulangan kata (majas repitisi/penegasan)

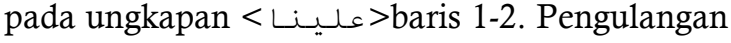
kata tersebut memberikan efek penegasan makna yang ingin disampaikan penulis. Pada pengulangan kata <ــــــmiliki makna tatkala Nabi Muhammad tiba kepada kita (kaum Anshar), maka wajiblah bagi kita (kaum Anshar) untuk mensyukurinya. Jadi pada ungkapan tersebut memberikan penegasan kewajiban bersyukur atas kaum Anshar. Selain itu, majas جـitisi juga ditemukan pada ungkapan $<$ baris 3-4. Pada pengulangan kata tersebut mengandung makna penekanan dan penegasan, terlihat dari penggalan kata جئت> >yang diletakkan pada awal kalimat baris keempat. Penulis ingin memfokuskan pada kata tersebut, bahwa pada baris 3-4 merupakan ungkapan kedatangan Nabi Muhammad SAW. Sehingga pada bait tersebut, antara baris 1-2 dan 3-4 menunjukkan penggalan kata (enjambement) yang menunjukkan makna penegasan serta masih berkaitan maknanya.

\section{Pembacaan Heuristik}

Berikut pembacaan heuristik pada lirik lagu $\mathrm{Al}$ Barq Al Yamani oleh Nissa Sabyan dan Adam Ali :

Bagian bait ke-1 :

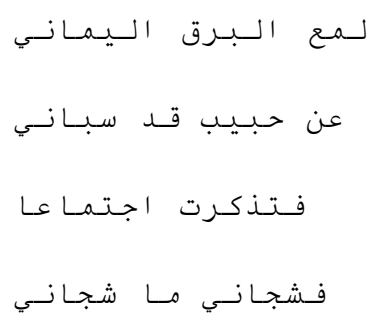

Lama al barqul yamānī

‘an habībin qad sabānī

Fatadzakkartuj timā'an

Fasyajānī mā syajānī

Kilat Yaman bersinar

(Teringat) tentang kekasih (yang) sungguh memikatku

Aku pun mengingat pertemuan (dengannya) Membuatku bersuka cita

Bagian bait ke-2 :

مستـاق و وبـد ري الــــبـ

من نـار الـجـوى عجب

Musytāqub sadrīl lahab

Min nāril jawā ${ }^{` a j a b}$

Aku rindu dan dadaku bergejolak

Dari api jarak (yang) menakjubkan Bagian bait ke-3 :

دمـعي على خدي انسكب 
أشكو هيـامي

Dam ‘̄ ‘alā khaddīn sakab

Asykū huyāmī

Air mataku tumpah mengalir di pipiku Sedekat (dengan) manusia terbaik Mengeluhkan kerinduanku

Bagian bait ke-4 :

To Madina I wanna go

I wanna soothe my aching soul

And see the green beatiful dome

And visit the best man of all

tu: Madina aI 'wpnə gəu

aı 'wpnə su:ð maı 'eıkın səol

ænd si: ðə gri:n 'bju:təful dəom

ænd 'vizit ðə best mæn pv o:1

Aku ingin pergi ke Madinah

Aku ingin menenangkan jiwaku (yang) sakit

Dan menyaksikan kubah hijau (yang) indah

Dan mengunjungi manusia terbaik

Bagian bait ke-5 :

In madina I'd love to be

And see the death come upon me

Be buried in Al Baqi

Close to the best human being

In Madina ard $1 \Lambda \mathrm{v}$ tu: bi:

ænd si: ðə d $\varepsilon \theta$ kım ə'ppn mi:

bi: 'berid In æl Baqi

kləus tu: ðə best 'hju:mən 'bi:In
Di Madinah aku ingin berada

Dan menyaksikan kematian menimpaku

Dimakamkan di Al Baqi

Bagian bait ke-6 :

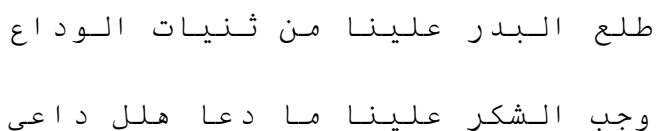

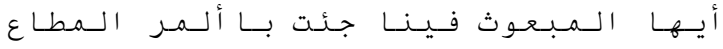

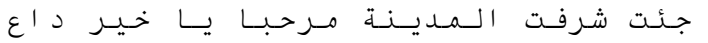

Param, pam, pam, param

Tala al badru 'alaynā min tsanīyatil wadā'i

Wajabal syukru ‘alaynā mā da'ā lillāhi dā'i

Ayyuhāl mab ūtsu fīnā ji'ta bil amril mutā'i

Ji'ta syarraftal madīnah marhaban yā khayra dā 'i Param, pam, pam, param

Telah nampak bulan purnama atas kita dari (arah) Tsaniat Wada'. Wajib(lah) kita bersyukur selama (sang) penyeru mengajak (kepada) Allah Wahai utusan kami, engkau datang dengan perintah (yang) dipatuhi Kedatanganmu telah memuliakan Madinah, selamat datang wahai sebaik-baik penyeru Param, pam, pam, param

\section{Pembacaan Hermeneutik}

Berikut pembahasan pembacaan hermeneutik masing-masing bagian per bait, hal ini dilakukan untuk mempermudah pemahaman pembacaan hermeneutik secara utuh :

Bagian bait ke-1 :

Bila ditinjau dari judul lagu "Al Barq Al Yamani/Kilat Yaman”, belum bisa diketahui secara jelas tema yang mendasari isi lagu tersebut. Pada bait ke-1 inilah mulai digambarkan pokok utama apa yang hendak disampaikan oleh penulis. Dimulai dari cahaya kilat menyilaukan yang muncul tiba-tiba di jantung langit dari sisi Yaman, seringkali membangkitkan keinginan 
dan kerinduan di dalam jiwa, rindu pada keluarga, kekasih dan tanah air. Manakala kilat bersinar, tergugah hati sang penulis mengingat perjumpaan dengan kekasihnya. Siapa kekasih disini belum digambarkan dengan jelas. Namun penulis menggunakan tokoh aku (kata ganti orang pertama) dalam syairnya yang terlihat sedang mencurahkan keluh kesahnya kepada lawan bicaranya. Ia sedang mengekspresikan bahwa bernostalgia mengingat kekasihnya membuatnya begitu bersuka cita, terlihat adanya majas repitisi (penegasan) pada baris terakhir yaitu pengulangan kata pada ungkapan شجـانـي bersuka cita. Penulis ingin mengekspresikan perasaan gembiranya yang berkobar-kobar.

Bagian bait ke-2 :

Pada bait tersebut, penulis ingin mengekspresikan kerinduanya kepada sang kekasih. Pada baris kedua menunjukkan bahwa sang kekasih berada jauh dari penulis, merupakan sebuah alasan begitu membaranya kerinduan si penulis. Kerinduannya tersampaikan melalui ketidaklangsungan ekspresi yang memberikan nilai estetis pada bait ini. Ungkapan "dadaku bergejolak" merupakan metafora yang menunjukkan makna bahwa sebegitu merindunya diumpamakan dengan nyala api yang berkobar

kobar. Kemudian ungkapan "api jarak yang menakjubkan" memberikan makna lain dari makna aslinya. Makna yang dimaksud ialah jauhnya jarak yang memisahkan, antara sang penulis dengan kekasih yang dirindukannya. Jadi ketika jarak yang jauh antara seseorang dengan orang yang dirindukannya, Ia akan merasakan $<$ > > yaitu api yang membara.

Bagian bait ke-3 :

Pada bait tersebut, penulis kembali ingin mengekspresikan kerinduanya pada sang kekasih. Begitu rindunya hingga ia meneteskan air mata. Bait ini juga menunjukkan adanya penegasan tentang kerinduanya pada sang kekasih yang telah disampaikan pada bait sebelumnya. Akan tetapi penegasan disini menggunakan bahasa yang sederhana yang membuat pembaca lebih mudah memahaminya.

Bagian bait ke-4 :

Lagu ini merupakan aransemen yang digabung dengan lagu lama lainnya yaitu Ayuhar
Rakbul Yamani, lagu yang selow dan romantis. Sehubungan dengan dilakukannya duet dengan Nissa Sabyan dan atas dasar mengutamakan keinginannya, Adam Ali merubah beberapa bagian lirik dan menggantinya dengan lirik berbahasa Inggris tentang Madinah supaya terdengar lebih modern. Inilah alasan mengapa terdapat lirik lagu yang menggunakan bahasa inggris.

Pada bait tersebut mengekspresikan beberapa keinginan si penulis, yang merupakan representasi dari kerinduan sang penulis, bahwa ia ingin mengobati rindunya dengan beberapa keinginan. Pertama ia ingin pergi ke Madinah, suatu kota bersejarah bagi umat muslim. Penulis ingin menenangkan jiwanya yang sakit disana. Maksud dari jiwa yang sakit disini ialah mengenai persoalan selama hidupnya yang membuat perasaan dan fikiranya tidak tenang. Pada baris ke1-2 belum dijelaskan tempat tujuan yang ingin ia kunjungi di Madinah. Kemudian pada baris ke3-4 mulai dijelaskan lebih spesifik, bahwa ia ingin menyaksikan Kubah Hijau, salah satu masjid di Madinah yang bernama Masjid Nabawi. Dijelaskan bahwa ia ingin mengunjungi manusia terbaik disana, akan tetapi belum dijelaskan siapakah manusia terbaik tersebut. Masjid Nabawi merupakan tempat dimana Nabi Muhammad SAW dimakamkan, jadi begitu melihat Kubah Hijau muncullah rasa bahagia karena mengingatkan kepada Rasulullah SAW. Nabi Muhammad SAW ialah manusia terbaik di muka bumi ini, karena beliaulah Rasul Allah SWT. Baris terakhir telah menunjukkan sosok manusia terbaik, bila merujuk pada poin-poin pendukungnya, Rasulullah SAW adalah sang kekasih yang dimaksud pada bait-bait sebelumnya.

Pada bait ini dijelaskan adanya penegasan dan penekanan makna keinginan yang berkelanjutan sang penulis, yaitu ditunjukkan oleh adanya 2 majas repitisi (penegasan) pada ungkapan "I wanna" dan "and".

\section{Bagian bait ke-5 :}

Pada bait tersebut penulis mengekspresikan kembali beberapa keinginanya. Setelah pada bait sebelumnya disampaikan bahwa ia ingin pergi ke Madinah, selanjutnya pada baris pertama bait ini ditegaskan kembali bahwa ia ingin menetap berada di Madinah. Kata "Madina" disini merupakan suatu pengulangan kata yang termasuk ke dalam majas repitisi (penegasan), yang mana kata sebelumnya 
terdapat pada bagian bait keempat. Pengulangan kata "Madina" tersebut memberikan penegasan makna, bahwa sang penulis berkeinginan kuat untuk pergi ke Madinah. Ia ingin menyaksikan kematiannya disana, yaitu dimakamkan di $\mathrm{Al}$ Baqi. Dimakamkan di Al Baqi merupakan suatu kemuliaan dan penuh berkah. Terselip harapan sang penulis akan keberkahan dan syafaat Rasulullah SAW, sehingga dengan begitu mampu menenangkan jiwanya yang sakit. Al Baqi merupakan pemakaman utama di Masjid Nabawi, merupakan tempat dimakamkanya para keluarga dan sahabat Rasulullah SAW. Pada baris terakhir bait ini, penulis menyebutkan kembali sosok manusia terbaik. Melihat beberapa poin yang disampaikan penulis, memperjelas bahwa tokoh sang kekasih yang dimaksud pada syair ini ialah Nabi Muhammad SAW.

Bagian bait ke-6 :

Pada bait tersebut, merupakan penggalan dari syair kaum Anshar (Tala al badru 'alaynā). Bait ini mengisahkan tentang penyambutan kaum Anshar untuk Nabi Muhammad SAW saat hijrah ke Madinah pada tahun $622 \mathrm{M}$. Madinah AlMunawarah merupakan kota suci yang memiliki cahaya di sekelilingnya karena keberkahan datangnya sang Nabi utusan Allah SWT. Lirik ini dilantunkan saat Nabi tiba di Madinah setelah melakukan perjalanan berminggu-minggu dengan Abu Bakar As Siddiq. Bait ini memberikan penekanan kembali bahwa tokoh sang kekasih yang dirindukan sang penulis adalah Nabi Muhammad SAW. Pada bait ini pula seakan mewakili kerinduan umat muslim terkhusus kaum Anshar pada saat menantikan kedatangan Rasulullah dari Makkah menuju Madinah. Bait ini juga mengandung pesan ajakan untuk bersyukur atas nikmat iman dan islam yang diajarkan Nabi Muhammad SAW sang penyeru dan utusan-Nya.

Kemudian adanya 2 majas repitisi (penegasan) yaitu pada ungkapan ("عــــ" atas kita dan "جـــ"/kedatanganmu) pada bait ini, sekaligus menunjukkan bahwa syair ini menyampaikan rasa gembira orang-orang Madinah dan bersyukurnya atas kedatangan Nabi Muhammad SAW.

\section{Matriks, Model dan Varian}

Model dari lirik lagu Al Barq Al Yamani (Kilat Yaman) adalah "kerinduan" dan "keinginan", karena keduanya mewaikili seluruh bunyi teks yang tertuang dalam keenam bagian bait. Keenam bait lirik lagu tersebut mencerminkan dua gagasan pokok. Yang pertama adalah tentang penulis yang begitu merindukan sang kekasih, terlihat dari bagaimana ia bernostalgia, dadanya yang bergejolak karena rindu, hingga ia meneteskan air mata. Yang kedua adalah sang penulis yang mempunyai beberapa keinginan untuk mengobati rindunya tersebut, terlihat bagaimana ia berulang kali mengungkapkan keinginanya tersebut.

Dari penjelasan aktualisasi model "kerinduan" dan "keinginan" tersebut, ditransformasikan menjadi varian-varian yang menyebar ke seluruh bait. Varian-varian tersebut ialah sebagai berikut :

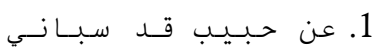

Teringat tentang kekasih yang sungguh memikatku

2. مسشتـاق و بـصد ري الـلـهـب

Aku rindu dan dadaku bergejolak

3. دمـــي علـى خـدي انـسكب

Air mataku tumpah mengalir di pipiku

4. طلـع الـبـد ر علـيـنـا مـن ثـنيـات الـود اع

Telah nampak bulan purnama atas kita dari arah Tsaniat Wada'

5. To Madina I wanna go

Aku ingin pergi ke Madinah

\section{In Madina I'd love to be}

Di Madinah aku ingin berada

Kemudian setelah diketahui model dan variannya, maka dapat diketahui bahwa matriks dari lirik lagu Al Barq Al Yamani ialah sang kekasih Allah, sosok manusia terbaik di muka bumi ini, yaitu Nabi Muhammad SAW sang penyeru dan utusan-Nya. Beliaulah sosok yang dirindukan oleh sang penulis, beliaulah tujuan dan maksud atas keinginan sang penulis mengunjungi Madinah. Nabi Muhammad SAW 
menjadi kata yang tidak tertulis dalam lirik lagu ini, tetapi selalu tersirat dalam setiap bait-baitnya.

\section{Hipogram}

Hipogram potensial pada lirik lagu ini adalah penjabaran dari matriks, yaitu sang kekasih Allah, sosok manusia terbaik di muka bumi ini, ialah Nabi Muhammad SAW sang penyeru dan utusan-Nya. Beliaulah sosok yang dirindukan oleh sang penulis, beliaulah tujuan dan maksud atas keinginan sang penulis mengunjungi Madinah. Nabi Muhammad SAW menjadi latar belakang terciptanya syair ini atas dasar perasaan rindu sang penulis, sehingga kerinduannya tertuang pada bait-bait syair ini. Kemudian hipogram aktual pada lirik lagu ini yaitu berinterteks dengan teks-teks syair kuno, diantaranya : syair kuno karya Al-Hajri abad 12 M, syair kuno Lama'al Barqul Yamani, syair kuno Ayuhar Rakbul Yamani serta Lagu Al Barq Al Yamani versi original oleh Harmony Band. Selain itu lirik lagu ini juga berhipogram dengan tempat bersejarah bagi umat muslim dan berkaitan erat dengan Rasulullah SAW, yaitu : kota Madinah, Kubah Hijau (Masjid Nabawi) dan pemakaman Al-Baqi.

\section{SIMPULAN}

Berdasarkan proses pembacaan dan penafsiran melalui metode ketidak langsungan ekspresi, pembacaan heuristik, pembacaan hermeneutik, mencari matriks, model dan varian serta hipogramnya maka dapat diperoleh makna lirik lagu Al Barq Al Yamani secara utuh. Keseluruhan bait dari awal hingga akhir menunjukkan makna yang berkesinambungan. Lirik lagu $A l$ Barq $A l$ Yamani (kilat Yaman) bercerita tentang kerinduan dan keinginan seseorang (penulis) kepada sang kekasih, Nabi Muhammad SAW. Sebuah penggambaran rasa rindu untuk berjumpa dan harapan untuk berada di sisinya. Kerinduan merupakan buah dari cinta. Rasa cinta kepada Nabi Muhammad SAW yang melahirkan kerinduan untuk berjumpa dan berada di sisinya.

Makna dari lirik lagu $A l$ Barq $A l$ Yamani juga tergambarkan melalui tempo lagu yang up-beat (cepat) serta nada lagu yang lebih kepada turun naik (fluktuatif). Hal ini disebabkan oleh perasaan yang ingin disampaikan penulis, yaitu gembira penuh suka cita dan rindu yang penuh harapan ingin bertemu. Gejolak emosi yang berkecamuk dalam hati sang penulis terepresentasikan dalam lirik tersebut, menjadikan nada dalam lagu ini fluktuatif. Sebagaimana denyut jantung yang berdebar-debar ketika akan bertemu dengan kekasihnya yang ia rindukan, seolah-olah waktu pun tidak ingin terlewatkan sedetikpun.

Tatkala kilat menyilaukan muncul tiba-tiba di jantung langit dari sisi Yaman, seringkali membangkitkan keinginan dan kerinduan di dalam jiwa, rindu pada keluarga, kekasih bahkan tanah air. Sang penulis bernostalgia, bersuka cita mengingat pertemuan dengan Nabi Muhammad SAW. Air matanya pun mengalir di pipinya, mengekspresikan rindunya yang sungguh bergejolak. Ia terpisah oleh jauhnya jarak dengan baginda Rasul. Atas dasar rindunya tersebut, Ia mengekspresikannya melalui harapan untuk pergi ke Madinah, menenangkan jiwanya yang sakit, fikiran dan perasaan yang tidak tenang karena persoalan hidupnya. Ia berkeinginan menyaksikan Kubah Hijau (Masjid Nabawi) yang begitu indah, mengunjungi makam Nabi Muhammad SAW. Sang penulis juga berharap, semoga kematian menimpanya di kota suci Madinah, dimakamkan di pemakaman Al-Baqi sedekat dengan Nabi Muhammad SAW.

Pada bagian bait terakhir (syair Tala'al badru 'alaynā) mengandung pesan dan makna ajakan untuk bersyukur atas nikmat iman dan islam yang diajarkan oleh Nabi Muhammad SAW sebagai sang penyeru dan utusan Allah SWT. Karena beliaulah, zaman terang benderang bisa tercapai.

\section{DAFTAR PUSTAKA}

Aritonang, D. A., \& Doho, Y. D. B. (2020). Analisis Semiotika Roland Barthes Terhadap Lirik Lagu Band Noah "Puisi Adinda". Jurnal Ilmu Komunikasi dan Bisnis, 4(2), 77-103.

Aryanto, B. (2013). Kajian Semiotik Riffaterre Dalam Konsep Cinta Sufisme Pada Kumpulan Puisi Syair Lautan Jilbab Karya Emha Ainun Nadjib Dan Pembelajaranya Di SMP Kelas VIII. 52. 
Fajrin, S. F. (2019). Semiotika Michael Camille Riffaterre Studi Analisis Alquran Dalam Surat AlBaqarah Ayat 223. Al Furqan, 2 Nomor 2, 149.

Harnia, N. T. (2021). Analisis Semiotika Makna Cinta pada Lirik Lagu "Tak Sekedar Cinta" Karya Dnanda. Jurnal Metamorfosa, 9(2), 224-238

Hidayat, R. (2014). Analisis Semiotika Makna Motivasi Pada Lirik Lagu "Laskar Pelangi" Karya Nidji. eJournal Ilmu Komunikasi, II(1), 244

Hosen, M., \& Ramadhani, R. S. (2020). Pesan Religi Pada Lirik Lagu Cinta (Analisis Semiotika Riffaterre Pada Lagu Populer Karya Grup Band Letto). Komunikasi dan sosial humaniora, 1(1), 4.

Imaduddin, M. F. (2018). Signifikasi Kisah Musa Dan Fir'aun Dalam Q.S Taha Perspektif Semiotika Riffaterre. 9.

Imron, M. (2018). Semiotika Dalam Lirik Lagu Arab Kun Anta Yang Dipopulerkan

Hidayat, R. (2014). Analisis Semiotika Makna Motivasi Pada Lirik Lagu "Laskar Pelangi" Karya Nidji. eJournal Ilmu Komunikasi. Samarinda: Fakultas Ilmu Sosial dan Ilmu Politik. Universitas Mulawarman.
Sari, Y. P. (2019). Makna Pesan Dakwah Dalam Lirik Lagu 'Deen Assalam'Cover Nissa Sabyan. Jurnal Dakwah Dan Komunikasi, 4(2), 187.

Nurdiansyah, C. (2018). Analisa Semiotik Makna Motivasi Berkarya Lirik Lagu Zona Nyaman Karya Fourtwenty. Jurnal Komunikasi, 9(2), 161-167.

Nugraha, R. P. (2016). Konstruksi Nilai-Nilai Nasionalisme Dalam Lirik Lagu (Analisis Semiotika Ferdinand De Saussure Pada Lirik Lagu "Bendera"). Jurnal Ilmu Ekonomi dan Sosial, 5(3), 290-303.

Nugraha, R. P. (2016). Konstruksi Nilai-Nilai Nasionalisme Dalam Lirik Lagu (Analisis Semiotika Ferdinand De Saussure Pada Lirik Lagu "Bendera"). Jurnal Ilmu Ekonomi dan Sosial, 5(3), 290-303.

Nugraha, R. P. (2016). Konstruksi Nilai-Nilai Nasionalisme Dalam Lirik Lagu (Analisis Semiotika Ferdinand De Saussure Pada Lirik Lagu "Bendera"). Jurnal Ilmu Ekonomi dan Sosial, 5(3), 290-303. 